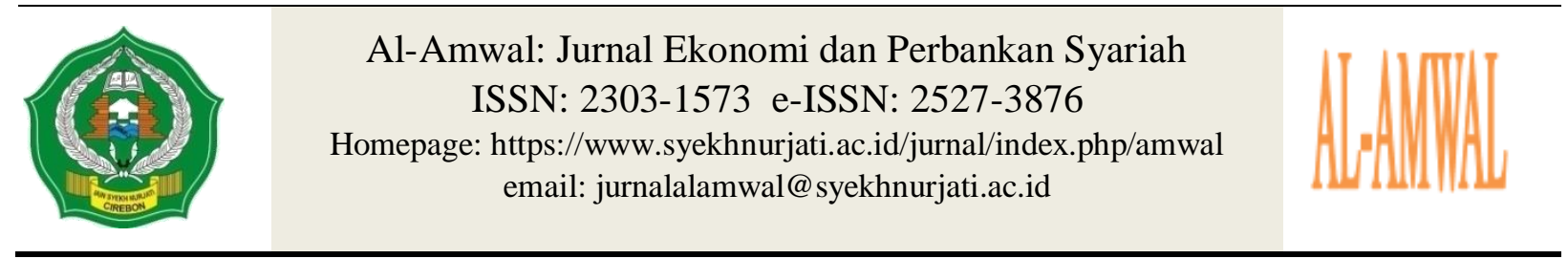

\title{
ANALYSIS OF INNOVATION ATTRIBUTES TOWARDS ADOPTION INTEREST OF SYARIAH BANK E-CHANNEL FACILITIES
}

\author{
Euis Widiati* \\ Faculty of Economic and Business, Sahid University \\ email: euis_widiati@usahid.ac.id, euiswidiati27@gmail.com \\ *Correspondence writer
}

\section{Budi Suharjo}

Department of Mathematics, Faculty of Mathematics and Natural Sciences, IPB University

\section{Diah Krisnatuti}

Department of Family and Consumer Sciences, Faculty of Human Ecology, IPB University

\begin{abstract}
The growth of sharia banking in Indonesia which is considered slow. This study aims to analyse communication and attributes of innovation as well as thelevel of awareness, interest and desire of consumers in adopting e-channel of sharia banks. The data wereobtained from 150 respondents selected by convenience sampling with the criteria of customers who havesavings accounts both in conventional and sharia banks, and who have one of the e-channel facilities inconventional bank. The data were analysed using PLS. This study is a type of quantitative research.Respondents were taken from the entire population of conventional and sharia bank customers in Jabodetabek (Greater Jakarta). The data were obtained by face-to-face interviews using questionnaire tools. The results suggested that respondents are generally aware of the existence of e-channel facilities of sharia banks.Respondents' interest in e-channel is influenced by the strengthening of awareness regarding the benefitsoffered. The respondents' high interest continues to the next stage, which is the interest in using echannels.
\end{abstract}

Keywords: Adoption, AIDA, Electronic channel, Inovation, Islamic Banking 


\begin{abstract}
Abstrak
Perkembangan tingkat pertumbahan bank syariah di Indonesia masih belum optimal. Penelitian ini bertujuan untuk menganalisis atribut inovasi pada tingkat kesadaran, ketertarikan, dan minat konsumen dalam mengadopsi $e$-channel bank syariah. Penelitian ini menggunakan 150 responden yang dipilih secara convenience sampling dengan kriteria yaitu nasabah multibank yang memiliki rekening tabungan di bank konvensional dan bank syariah, serta memiliki salah satu fasilitas e-channel pada bank konvensional. Data dianalisis menggunakan PLS. Responden diambil dari seluruh populasi nasabah bank konvensional dan bank syariah di wilayah Jabodetabek. Data dikumpulkan dengan cara face to face interview menggunakan alat bantu kuesioner. Hasil penelitian menunjukkan bahwa responden pada umumnya telah mengetahui keberadaan fasilitas e-channel bank syariah. Ketertarikan responden terhadap e-channel dipengaruhi oleh penguatan kesadaran terkait manfaat yang ditawarkan. Tingginya ketertarikan responden berlanjut ke tahap selanjutnya yaitu berminat untuk menggunakan e-channel.
\end{abstract}

Kata kunci: Adopsi, AIDA, Electronic channel, Inovasi, Islamic Banking

\title{
INTRODUCTION
}

Currently, it has been more than a decade since the introduction of the Islamic banking system in Indonesia, however, the growth in the ratio of assets of Islamic banks to total banks in Indonesia is still not optimal. One of the reasons is the ineffective marketing strategy in terms of communication and outreach to the public. The presence of Islamic banking finance among people who are accustomed to using financial service facilities from conventional banks creates a multi-bank phenomenon. It is now possible for a person to have an account and become a customer of more than one bank, be it conventional banks, Islamic banks, or both.

This condition will be an opportunity for Islamic banks to be able to compete with conventional banks in providing banking services, so that Islamic bank products can be an alternative choice for consumers. However, even Islamic banks must have the advantage of their products over conventional banks. The goals and objectives to be achieved are for multibank customers to use their transactional facilities at Islamic banks as their main choice.

The current development of information technology is no longer a stranger to the people of Indonesia, because the information technology has provided many benefits in helping to run the economy more effectively and efficiently. This information technology test refers to research on the impact of Information Technology (IT) on organizational and banking performance. According to (Shaukat\&Zafarullah, 2010) that the most users of information technology are the financial sector, especially banking. Because through this information technology, banking in the financial sector can process various kinds of electronic data that can reach all over Indonesia and the world.

According to (Pooja\&Singh, 2009) based on univariate analysis, banks that provide e-channels are more profitable and more efficient in terms of operations than banks that do not use e-channels. In addition, banks that provide e-channels also have better asset quality and are better at managing costs for buildings and equipment.

In Indonesia, the practice of internet banking was pioneered by a national private bank. Currently, there are around 62 conventional banks that provide delivery channel services, and nine Islamic banks. This amount is a form of development and 
improvement of the banking industry, now the e-channel is at the transactional stage, no longer informational (or just a website). According to (Margaretha, 2015) for banks that use e-channel services or those that don't, have an influence on the performance of the bank concerned. In addition, the size of the assets owned by the bank also has a positive effect on the use of e-channels.

An innovation takes a long time, it can even take years from its availability until it is widely adopted by society. (Morissan et al.2013) explained that some people will adopt sooner or take longer to try something new, while others are able to take longer, and so on. There is also an individual who already knows an innovation but does not want to adopt it or refuses to use it.

This research will specifically discuss the attributes of innovation towards the interest in adopting e-channel facilities in Islamic banks for multi-bank customers, so that the hope is to increase the number of customers, e-channel users and their transactional volume in Islamic banks. This is a strategic step to increase fee-based income in Islamic banks, so as to increase the market share of Islamic banking in Indonesia.

Nowadays many people have accounts at different banks (multibank). In the multi-bank case, the community not only saves their funds in conventional banks, but also in Islamic banks. Generally, people who have become customers of Islamic banks are conventional bank customers. But in fact this has not seen any changes. According to (Setiawan, 2013) system and service quality is the most dominant variable influencing the attitudes of e-channel users. In addition, consumer behavior in the financial services industry is changing rapidly, consumer perceptions and reactions to information technology and banking technology are significant studies of this research. Understanding consumer behavior in the context of e-banking will provide a relatively important theoretical background for future research in the field of electronic business. In addition, research results have provided a basis for marketing strategies related to the development of electronic banking services (e-banking).

Another important thing that banks need to pay attention to in developing echannel transaction facilities is the security of customer data privacy. Perceptions of privacy commitment have a positive and significant effect on the perceived value of ebanking. Therefore, if the perception of a bank's privacy commitment in safeguarding customer personal information is getting more positive or better, then the perceived value of e-banking services will also increase (Purnami, 2015).

In the last few years, Islamic banks have developed an innovation in the form of e-channel as a pull factor, which is expected to be able to attract people to switch to using their financial activities in Islamic banks. If it is seen that the use of e-channel facilities is part of sharia banking innovation, then it is important to examine the level of awareness, interest and interest of consumers in adopting Islamic bank e-channel. In addition, because innovation is part of something that can make someone more effective and efficient. So the use of e-channels is also something that is synonymous with these innovations. So it is necessary to know what factors influence innovation adoption? According to Rogers (1995) there are many factors that influence the adoption of innovation, in this case the e-channel facility, namely relative advantage, compatibility, complexity, triability, and observability. 


\section{LITERATURE REVIEW Electronic Channel}

According to (Abbad, 2013) the main objective of his research is to study customer acceptance of e-banking in the context of the Technology Acceptance Model (TAM). TAM was expanded by adding new variables derived from e-banking acceptance literature and interviews with e-banking specialists. The data shows that as a hypothesis, customer intention to use e-banking is influenced by Perceived Ease Of Use (PEOU), Perceived Usefulness (PU), subjective norms, internet experience, security and trust, and enjoyment. In a study conducted by the Directorate of Banking Research and Regulation, Bank Indonesia (2002) explained that in addition to cost savings, there are several benefits expected by banks in the application of internet banking, including:

1. Increase the number of customers, considering that more and more people today use the internet. In addition, customers at this level usually have considerable financial capacity.

2. Market demands that bank services are paperless, timeless and borderless oriented.

3. Contagion willingness, due to the influence of other banks on the same peer having implemented internet banking.

4. Build an image and increase the level of competition, especially for banks that are not widely known to the public.

5. Expanding the service network, which based on economic and geographic analysis is more profitable and easier to implement internet banking compared to opening branch offices.

6. Information collection, especially information regarding banking market desires. Faster and up to date absorbed through internet banking.

7. Internet banking installations are getting cheaper and cheaper due to company competition among internet service providers.

8. The absence of prudential provisions specifically regulating internet banking, for example regarding licensing and requirements so that banks feel free to operate internet banking.

E-banking service quality factors and research results indicate that the quality features of e-banking services can be categorized into Convenience, Access, Security, and Website Interface. This study has found security as a supporting factor, because the quality of e-banking services must rely on security software to increase trust (Kusumaningtyas \& Rahajeng, 2017).

E-banking offers significant benefits that lead banks to improve and develop new e-banking services and channels. The integration of heterogeneous, autonomous, and distributed data sources is an essential and hard issue in e-banking. In addressing integration issues, service-oriented architecture (SOA) is introduced by many organizations including banks (Themistocleous et al., 2015).

\section{Diffusion of Innovation}

According to (Thambiah, 2012) the research findings indicate that there is a significant difference between urban and rural customers in their awareness of Islamic Retail Banking (IRB). Respondents view IRB's products and services as complex services and feel the complexity is likely to be greater for rural and non-Muslim customers, compared to Muslim customers in urban areas. Based on the findings, the Innovation Diffusion Theory (IDT) Model can be extended by including two new 
variables that are identified as significant; consumer awareness and promotional efforts towards the use of the IRB and the intention to use the IRB.

\section{AIDA Model}

Research conducted byIrfan (2011) in Analysis of the Effectiveness of One Rinse Molto Ultra Promotion (MUSB) on Water Saving Behavior measures the effectiveness of promotion in terms of water saving campaigns based on the innovation adoption model, analyzes the factors that play a role in the process of adopting MUSB product innovation and analyzing the adopters of the product innovation. In addition, Ihsani (2018) conducted a study combining the AIDA theory and the adoption of Invosi on the use of the Halal MUI application in Bogor City. This research uses variables of communication, technology, religiosity, awareness, interest, desire, and adoption.

The AIDA model describes a person's stages starting from awareness of the product, interest in the product, desire to use, to finally using the product. As research conducted by Rehman et al.(2014) about how the AIDA model can effectively influence consumers. This research explains that the AIDA model can be applied in traditional marketing and digital marketing. That customer service signifies a pronounced part in the intentions of customers to adopt electronic banking. Bank customers have discovered ecustomer service to be imperative in luring customers' intentions to electronic banking adoption(Marunyane, 2018).

The adoption rate for e-banking is different across economies. For example, absorption rates in developed countries are significantly higher than in developing countries. In addition, there are security and privacy risks associated with conducting online financial activities that need to be addressed (Mujinga et al., 2018). Adoption of e-banking services in South Tangerang city is influenced by all TAM (Technology Acceptance Model) variables, such as perceived usefulness, perceived ease of use, economic sacrifice, and attitude toward using, behaviour intention, and actual use (Riantini \& Wandrial, 2018).

\section{METHOD}

This research was conducted in January-September 2018 which was conducted in the Jabodetabek area. The consideration of choosing the region is because it is considered to represent the diversity of demographic characteristics of the Indonesian people. The quantitative approach was chosen for reasons of identifying, determining, and explaining the existing characteristics of the target population under study.

\section{Sample Procedure}

The population in this study were multibank customers who live in the Jabodetabek area. The criteria for respondents as samples in this study are customers who already have accounts at conventional banks and also Islamic banks. The number of respondents in this study were 150 multibank customers.

\section{Operational variables}

In this study, the sampling technique was carried out based on the non-probability sampling method, namely by convenience sampling which was carried out based on the determination of the respondent's criteria. Respondents will be interviewed directly (face to face interview) with a guide to a list of questions or a structured questionnaire (structured questionnaire). 
This study uses primary data and secondary data. Primary data is obtained from respondents' responses through questionnaires and interviews with people who have become customers in conventional banks and Islamic banks. Meanwhile, secondary data were obtained from Bank Indonesia, OJK, a number of scientific publications, journals and books as supporting data.

\section{Analysis Technique}

This research was conducted using two analyzes, including descriptive and statistical analysis. The statistical analysis used in this study is the Structural Equation Model (SEM) with the Partial Least Square (PLS) method.

This research is based on Rogers' Innovation Adoption theory and AIDA response hierarchy theory, so the conceptual model in this study can be seen in Figure 1.

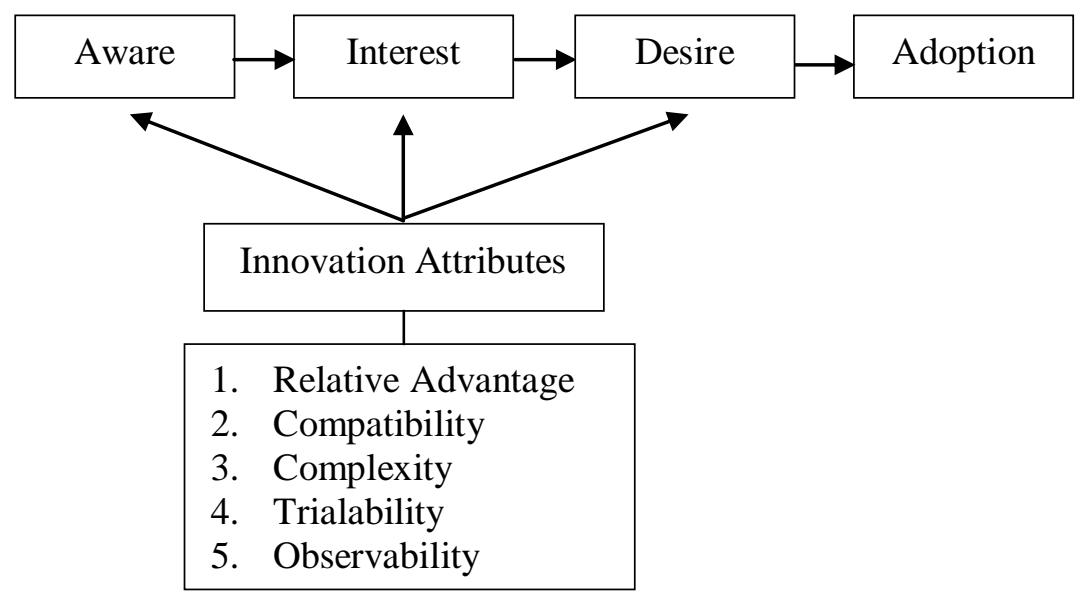

Figure 1 Research Framework

\section{RESULT AND DISCUSSION}

Responden yang terlibat dalam penelitian ini berjumlah 150 orang. Tabel 1 Respondents involved in this study amounted to 150 people. Table 1 shows the characteristics of the respondents.

Table 1 Demographic Characteristics of Respondents

\begin{tabular}{cccllc}
\hline & Category & $(\boldsymbol{\%})$ & & Category & $\mathbf{( \% )}$ \\
\hline Sex & Male & 42 & Education & High School & 14 \\
& Female & 58 & & Diploma & 9 \\
& & & Bachelor & 67 \\
& & & Postgraduate & 9 \\
Age & $17-25$ yo & 27 & Occupation & Civil servants & 7 \\
& $26-34$ yo & 52 & & BUMN employee & 8 \\
& $35-41$ yo & 13 & & Private employees & 67 \\
& $42-50$ yo & 4 & Professional & 2 \\
& $>51$ yo & 3 & Entrepreneur & 4 \\
& & & College student & 10 \\
& & & Others & 2 \\
\hline
\end{tabular}




\section{Measurement Model Fit Test (Outer Model Evaluation)}

The fit test of the measurement model or outer model is carried out to assess the validity and reliability of the construct, through two stages, namely evaluation of the first order construct which is formed by its indicators and evaluation of the second order construct, which is the construct formed by the first order construct which becomes its dimension. The criteria for the suitability of the measurement model are measured based on the validity of the indicator variable against the latent variable. An indicator is said to be valid if it has a loading factor value of more than 0.5 and has a t-count above 1.96 . After doing two calculations, an indicator value that meets the validity requirements is obtained and can be used for further analysis. Meanwhile, indicators that do not meet the requirements will be eliminated. The value of the loading factor (loading factor) which shows the contribution of each variable.

Testing construct reliability or latent variables can be measured by looking at the composite reliability value of the indicator block measuring the construct. The construct of a variable is said to be consistent enough if the variable has a composite reliability value above 0.70 . Table 2 shows the value of composite reliability and AVE.

Table 2 Value of composite reliability and AVE of the second order construct

\begin{tabular}{lcc}
\hline Variable & Composite Reliability & AVE \\
\hline Awareness & 1,000000 & 1,000000 \\
Interest & 1,000000 & 1,000000 \\
Desire & 1,000000 & 1,000000 \\
Adoption & 1,000000 & 1,000000 \\
Inovation & 0,907745 & 0,663780 \\
\hline
\end{tabular}

The latent variable with an AVE value above 0.5 means that on average the latent variable can explain more than half of the diversity of the indicator. Based on the results in Table 2, all constructs are above the value of 0.70 . Thus it can be concluded that all constructs have good reliability in accordance with the minimum limit required, so that all first order constructs are valid in measuring different aspects of the second order construct.

\section{Structural Model Fit Test (Inner Model Evaluation)}

The structural model fit test is carried out by looking at the coefficient of determination (R2) and the value of the path coefficient. After the suitability of the overall model has been analyzed, the next step is to test the suitability of the structural model carried out against the structural equation coefficients.Koefisien Determinasi $\left(\mathrm{R}^{2}\right)$.

Testing the coefficient of determination is used to see how much influence the independent latent variable (exogenous variable) has on the dependent latent variable (endogenous variable).

Table 3 R-Square value for each endogenous variable

\begin{tabular}{ll}
\hline & R-Square \\
\hline Awareness & 0.209003 \\
Interest & 0.167933 \\
Desire & 0.708658 \\
Adoption & 0.449397 \\
\hline
\end{tabular}


Based on the value of R2, it can be obtained information that the model built is able to explain the diversity of desire for $70.86 \%, 44.93 \%$ adoption, $20.90 \%$ awareness, $16.79 \%$ interest.Path Coefficient $(\beta)$ values that are in the range of -0.1 to 0.1 are considered insignificant, values greater than 0.1 are significant and directly proportional to values, and values less than -0.1 are significant and inversely proportional.

\section{Hypothesis test}

The hypothesis testing stage is carried out after the structural model evaluation stage is carried out. The decision making in testing this hypothesis is to reject $\mathrm{H}_{0}$ if the t-count value is greater than the t-table value with a significance level $(\alpha)$ of $5 \%$, which is 1.96. Table 4 shows the results of hypothesis testing in the research model.

Table 4 Results of hypothesis testing in the research model

\begin{tabular}{clccc}
\hline $\begin{array}{c}\text { Hypot } \\
\text { hesis }\end{array}$ & \multicolumn{1}{c}{ Path } & $\begin{array}{c}\text { Coefficient } \\
\text { path }\end{array}$ & $\begin{array}{c}\mid \mathbf{t} \text {-test } \mid \\
\mathbf{1 , 9 6}\end{array}$ & Information \\
\hline H1a & Innovation $\rightarrow$ Interest & 0.267384 & 2.317840 & Significant \\
H1b & Innovation $\rightarrow$ Desire & 0.134907 & 1.658196 & Not significant \\
H1c & Innovation $\rightarrow$ Adoption & -0.140807 & 1.829421 & Not significant \\
H2a & Awareness $\rightarrow$ Interest & 0.269470 & 2.748160 & Significant \\
H2b & Interest $\rightarrow$ Desire & 0.791010 & 10.393010 & Significant \\
H2c & Desire $\rightarrow$ Adoption & 0.692174 & 9.374312 & Significant \\
\hline
\end{tabular}

Information:

If $\mid t$-test $\mid>1.96$, it means that there is a significant influence between the latent variables

The results indicated by the direct influence of the innovation variable on the latent interest variable, namely the significant influence between innovation on the interest in using e-channel. This condition is in line with research by (Yani et al., 2018) that the perceived benefit of use of the internet has a direct influence on the perception of ease of use of the internet in transactions for customers. The more benefits that are felt by customers, the more convenience they will feel when making transactions using e-banking.

In contrast to what happened to the relationship between innovation and desire, it shows that innovation does not have a significant effect on respondents' interest in using e-channels. This analysis contradicts the research (Indah, 2016) that e-banking has an influence on customer loyalty. However, e-banking also requires improvements in the convenience provided to customers. This is in line with research by (Kusumaningtyas \& Rahajeng, 2017) which states that ATM and e-banking services should make designs that are easier to use, namely by way of menus that are not gradual and do not require a long time.

There is an influence between awareness and interest in e-channels. The path coefficient value shows that the direction of the relationship is positive, meaning that awareness of e-channel facilities can increase interest in e-channel facilities. This analysis is supported by (Ramavhona \& Mokwena, 2016) whereas the lack of awareness about internet banking services and its benefits such as convenience and the possibility to conduct banking transactions from any location may be a reason for retail banking consumers to adopt internet banking.

The relationship between interest to desire explains that there is an influence between interest and desire on the e-channel. The path coefficient value shows a positive relationship, meaning that a sense of interest in e-channel facilities can increase 
interest in using e-channel facilities. And it can be concluded that there is an influence between desire and the adoption of e-channels. The path coefficient value shows a positive direction of the relationship, meaning that with a sense of interest in e-channel facilities it can increase decisions in using e-channels.

\section{CONCLUSION}

Based on the results of research on the attributes of innovation in Islamic bank e-channel facilities, it can be concluded that respondents generally already know the existence of Islamic bank e-channel facilities. Respondents' interest in Islamic bank echannel facilities is influenced by the strengthening of awareness regarding the benefits offered by e-channels. The high interest of respondents continues to the next stage, namely interested in using e-channel facilities.

\section{REFERENCES}

Abbad, M. M. (2013). E-Banking in Jordan. Behaviour and Information Technology, 32(7), 681-694. https://doi.org/10.1080/0144929X.2011.586725

Indah, D. R. (2016). Pengaruh E-Banking dan Kualitas Pelayanan terhadap Loyalitas Nasabah pada PT. Bank BNI'46 Cabang Langsa. Jurnal Manajemen Dan Keuangan Unsam, 5(2), 545-554.

Kusumaningtyas, R. H., \& Rahajeng, E. (2017). Persepsi Nasabah Akan Layanan Atm Dan E-Banking Dengan Metode TAM. Jurnal Sistem Informasi, 10(2), 89-102. https://doi.org/10.1090/S0002-9939-02-06464-X

Margaretha, F. (2015). Dampak Electronic Banking Terhadap Kinerja Perbankan Indonesia. Jurnal Keuangan Dan Perbankan, 19(3), 514-524.

Marunyane, G. (2018). Underpinning Determinants of Consumer'S Intention To Adopt Electronic Banking: a Developing Country'S Perspective. The International Journal of Organizational Innovation, 11, 1-15. http://www.ijoi-online.org/

Mujinga, M., Eloff, M. M., \& Kroeze, J. H. (2018). System usability scale evaluation of online banking services: A South African study. South African Journal of Science, 114(3-4), 50-58. https://doi.org/10.17159/sajs.2018/20170065

Pooja, M., \& Singh, B. (2009). The Impact of Internet Banking on Bank Performance and Risk: The Indian Experience. Eurasian Journal of Business and Economics, 2(4), 43-62. https://doi.org/10.1057/palgrave.jbr.2340189

Purnami, N. M. (2015). Dukungan OPT-OUT dan Persepsi Nilai E-Banking. Jurnal Keuangan Dan Perbankan, 19(3), 1-15.

Ramavhona, T. C., \& Mokwena, S. (2016). Factors influencing Internet banking adoption in South African rural areas. South African Journal of Information Management, 18(2), 1-18. https://doi.org/10.2224/sbp.2016.44.9.1443

Riantini, R. E., \& Wandrial, S. (2018). Adoption of e-banking services in south tangerang using Technology Acceptance Model (TAM) approach. Pertanika Journal of Social Sciences and Humanities, 26(T), 161-172.

Setiawan, H. (2013). Faktor Individu, Organisasi, Dan Sistem Terhadap Sikap Pengguna E-Banking. Jurnal Keuangan Dan Perbankan, 17(1), 147-155.

Shaukat, M., \& Zafarullah, M. (2010). Impact of Information Technology on Organizational Performance: An analysis of quantitative performance indicators of Pakistan's banking and manufacturing companies. International Research Journal of Finance and Economics, 39, 229-243.

Thambiah, S. (2012). A Study On Consumer Adoption Of Islamic Retail Banking 
Services In Malaysia.

Themistocleous, M., Basias, N., \& Morabito, V. (2015). A Framework for Serviceoriented Architecture Adoption in e-Banking: the Case of Banks from a Transition and a Developed Economy. Information Technology for Development, 21(3), 460479. https://doi.org/10.1080/02681102.2014.939605

Yani, E., Lestari, A. F., Amalia, H., \& Puspita, A. (2018). Pengaruh Internet Banking Terhadap Minat Nasabah Dalam Bertransaksi Dengan Technology Acceptance Model. Jurnal Informatika, 5(1), 34-42. https://doi.org/10.31311/ji.v5i1.2717 